\title{
PELATIHAN PENULISAN ARTIKEL ILMIAH PADA GURU- GURU SEKOLAH DASAR KECAMATAN SUNGAI RAYA KABUPATEN KUBU RAYA
}

\author{
Muhammad Anwar Rube'i ${ }^{1}$, Syarif Firmansyah ${ }^{2}$, Moad $^{3}$ \\ 1,2,3 Program Studi PPKn Fakultas Ilmu Pendidikan dan Pengetahuan Sosial \\ IKIP PGRI Pontianak, Jalan Ampera Nomor 88 Pontianak \\ 1e_mail: anwarptk87@gmail.com
}

\begin{abstract}
Abstrak
Tujuan kegiatan pengabdian adalah untuk memberikan pelatihan penulisan artikel untuk publikasi ilmiah. Sasaran kegiatan adalah guru-guru SD se-Kecamatan Sungai Raya sebanyak 30 guru. Pelaksanaan pengabdian di Sekolah Dasar Islam Daarul Hikmah. Metode pengabdian yang digunakan adalah ceramah, tanya jawab, diskusi, penugasan, dan Pendampingan. Kegiatan pengabdian mulai dari tahap persiapan yakni observasi dan sosialisasi, sedangkan untuk pelaksanaan mulai dari penyajian materi, praktik, refleksi, dan evaluasi. Hasil kegiatan pengabdian adalah: (1) Terdapat peningkatan kepercayaan dan pemahaman tentang karya tulis ilmiah bagi pendidik mendesain laporan penelitian menjadi artikel imiah yang layak publikasi di jurnal ilmiah; (2) Kegiatan pengabdian masayarakat berupa pelatihan menulis artikel ilmiah telah berhasil dilaksanakan dengan baik dan lancar, keberhasilan ditunjukkan dengan peserta pelatihan dapat menjelaskan pengetahuan tentang pengertian penulisan artikel ilmiah, memahami jenis-jenis artikel ilmiah, dan mengetaui macam-macam jurnal ilmiah yang menjadi media untuk mempublikasikan jurnal; (3) Meningkatknya pengetahuan dan keterampilan peserta dalam menulis artikel ilmiah yang sesuai dengan pedoman atau template penulisan artikel ilmiah; dan (4) Peserta pelatihan telah menghasilkan artikel ilmiah yang siap untuk dipublikasikan di jurnal ilmiah.
\end{abstract}

Kata Kunci: pelatihan penulisan, artikel ilmiah, publikasi ilmiah,

\begin{abstract}
The purpose of the devotion activity is to provide training in writing articles for scientific publications. The activity targets are teachers of SD Se-Kecamatan Sungai Raya by 30 teachers. Implementation of dedication in Islamic Elementary School Daarul Hikmah. Methods of devotion used are lectures, questions and answers, discussions, assignments and mentoring. Activities of devotion start from the preparation stage of observation and socialization, while for the implementation starting from the presentation of materials, practice, reflection and evaluation. The results of the service activities are: (1) There is an increase in the trust and understanding of scientific papers for educators designing the research report into a decent imitation articles publication in Scientific Journal (2) Community service activities in the form of training of scientific article writing has been successfully carried out well and smoothly, this success is demonstrated by the teacher of the trainee to explain the knowledge about the understanding of scientific article writing, to understand the types of scientific articles and to know the various scientific journals that become the media to publish the journal. (3) the increased knowledge and skills of the participants in writing scientific articles in accordance with guidelines or templates for writing scientific articles. (4) Teacher trainees have produced scientific article products ready for publication in scientific journals.
\end{abstract}

Keywords: writing article, scientific articles, scientific publications. 


\section{PENDAHULUAN}

Guru merupakan pendidik profesional yang mempunyai tugas, fungsi, dan peran untuk mencerdaskan anak bangsa. Guru yang profesional diharapkan mampu mewujudkan peserta didik yang bertakwa kepada Tuhan Yang Maha Esa, berakhlak mulia, sehat, berilmu, cakap, kreatif, mandiri, dan menjadi warga negara yang demokratis serta bertanggung jawab seperti yang diamanatkan dalam Undang-Undang Nomor 20 Tahun 2003 tentang Sistem Pendidikan Nasional. Tidaklah berlebihan kalau dikatakan bahwa masa depan masyarakat, bangsa, dan negara, sebagaian besar ditentukan oleh guru. Profesi guru perlu dikembangkan secara terus-menerus dan proporsional menurut jabatan fungsional guru. Agar fungsi dan tugas yang melekat pada jabatan fungsional guru dilaksanakan sesuai dengan aturan yang berlaku, maka ditetapkan beberapa peraturan perundangan yang mengatur tentang profesi guru.

Guru sebagai tenaga profesional mempunyai fungsi, peran, dan kedudukan yang sangat penting dalam mencapai visi pendidikan 2025, menciptakan insan Indonesia cerdas dan kompetitif. Guru profesional tidak cukup hanya berkonsentrasi pada tugas utamanya mendidik, mengajar, membimbing, mengarahkan, melatih, menilai, dan mengevaluasi peserta didik seperti tersebut pada Undang-Undang Guru dan Dosen, tetapi harus melakukan kegiatan Pengembangan Keprofesian Berkelanjutan (PKB). Program PKB dilaksanakan oleh setiap guru. Jenis kegiatan sesuai dengan kebutuhan guru untuk mencapai standar kompetensi profesi dan/atau meningkatkan kompetensinya diatas standar kompetensi profesinya yang sekaligus berimplikasi kepada perolehan angka kredit untuk kenaikan pangkat/jabatan fungsional guru. PKB mencakup tiga hal yaitu pengembangan diri, publikasi ilmiah, dan karya inovatif (Kemendikbud, 2012: 8).

Berdasarkan uraian tersebut, dapat dijelaskan bahwa bagi guru, kepala sekolah, dan pengawas yang akan mengusulkan kenaikan pangkat, wajib melaksanakan kegiatan pengembangan diri, yaitu salah satunya adalah publikasi ilmiah/karya tulis ilmiah. Keputusan Menteri Negara Pendayagunaan Aparatur Negara Reformasi Birokrasi Nomor 16 Tahun 2009 tentang Penetapan Jabatan Fungsional Guru dan Angka Kreditnya dan Keputusan Bersama Menteri 
Pendidikan Nasional dan Kepala Badan Kepegawaian Negara Nomor 14 Tahun 2010 tentang Petunjuk Pelaksanaan Jabatan Fungsional Guru dan Angka Kreditnya, serta Permendiknas Nomor 35 Tahun 2010 tentang Petunjuk Teknis Pelaksanaan Jabatan Fungsional Guru dan Angka Kreditnya, pada prinsipnya adalah bertujuan untuk peningkatan profesionalisme dan pembinaan karier kepangkatan guru. Hal tersebut berarti bahwa ada syarat mutlak yang harus dilakukan guru untuk kenaikan pangkat/jabatan mulai dari III-a keatas, yaitu kegiatan pengembangan keprofesian berkelanjutan oleh guru yang berupa pengembangan diri, publikasi ilmiah, dan karya inovatif.

Jabatan Guru Pertama dengan pangkat Penata Muda golongan ruang III/a menuju Penata Muda Tingkat I, golongan ruang III/b, para guru sudah dipersyaratkan minimal mengisi 3 (tiga) angka kredit pengembangan diri. Dari golongan ruang III/b ke III/c dipersyaratkan minimal mengisi 4 (empat) angka kredit unsur publikasi ilmiah dan/atau karya inovatif. Hal tersebut sampai pada golongan IV/e dengan angka keridit minimal 20 (dua puluh) untuk publikasi ilmiah dan/atau karya inovatif. Dengan adanya proses kumulatif mencapai angka standar yang ditentukan tentu akan memberi kemudahan bagi guru dalam mengisi kegiatan pengembangan profesi. Kegiatan pengembangan profesi bersifat berkelanjutan tersebut juga akan membantu guru dalam melakukan pembenahan dalam pembelajarannya dengan melakukan kegiatan-kegiatan publikasi ilmiah sehubungan dengan tugas seorang guru sebagai pengajar dan pendidik. Pembenahan yang dilakukan guru dalam kegiatan pembelajaran akan membuat guru tersebut semakin profesional di bidangnya.

Sistem angka kredit tentu diharapkan akan semakin adil tentang jabatan/pangkat yang diperoleh guru sesuai dengan keprofesionalannya secara optimal. Salah satu keprofesionalan guru tersebut ditandai dengan kemampuan guru dalam melakukan pengembangan keprofesionalannya yaitu melakukan Kegiatan Publikasi Ilmiah (KPI) ke dalam jurnal nasional. Menurut Sikula (1981) pelatihan adalah proses pendidikan jangka pendek dengan menggunakan prosedur yang sistematis dan terorganisir, sehingga karyawan operasional belajar pengetahuan, teknik pengerjaan, dan keahlian untuk tujuan tertentu. 
Pendidikan dan pelatihan merupakan kegiatan yang tidak dapat dipisahkan dalam rangka pengembangan kualitas sumber daya manusia, yang substansinya menyangkut aspek proses perencanaan, penempatan, dan pengembangan tenaga kerja manusia. Menurut Sudjana (2004) pelatihan dapat dikaji dari aspek pengembangan sistem, model, dan pengelolaan pelatihan. Dari segi pengembangan sistem, pelatihan memiliki komponen input (masukan), process (proses), dan output (keluaran). Unsur masukan meliputi masukan lingkungan (environmental input), masukan sarana (instrumental input), masukan bahan mentah (raw input), dan masukan lainnya (others input). Unsur proses (processes) merupakan interaksi semua komponen input dalam pelatihan, unsur output, dan outcome yang terdiri dari output kognisi, keterampilan, dan sikap serta nilai.

Kebijakan peningkatan mutu guru dilaksanakan dalam berbagai bentuk kegiatan pendidikan di lembaga pendidikan tenaga kependidikan (preservice education), pendidikan dan pelatihan (in-service training), dan pendidikan dalam jabatan (on the job training) (Suparlan, 2006: 118). Menurut Handoko (2003: 243) tujuan latihan dan pengembangan adalah untuk memperbaiki efektivitas kerja dalam mencapai hasil kerja yang telah ditetapkan. Latihan dimaksudkan untuk memperbaiki penguasaan keterampilan dan teknik pelaksanaan pekerjaan tertentu, terperinci, dan rutin. Pengembangan mempunyai lingkup lebih luas dalam peningkatan kemampuan, sikap, dan sifat kepribadian. Tujuan pelatihan menurut Kenna (2000: 145) menambah pengetahuan, keterampilan, dan mengubah sikap.

Pelatihan publikasi ilmiah dalam kegiatan pengabdian mengacu pada fungsi manajemen mulai dari perencanaan, pengorganisasian, pengarahan, pelaksanaan tindakan, pengembangan, dan pengendalian. Menurut Amrullah (2004: 12) perencanaan meliputi aktivitas untuk menentukan tujuan dan sasaran yang akan dicapai, serta langkah strategis yang akan diambil untuk mencapai tujuan yang telah ditetapkan. Mengacu pada konsepsi tersebut, maka kegiatan pelatihan didahului dengan penetapan tujuan yang akan dicapai, penyusunan langkah strategis meliputi rancangan kriteria peserta, pelatih, materi, dan strategi pembelajaran. Dalam perencanaan kinerja diperlukan eksplorasi bersama tentang 
apa yang perlu diketahui dan dilakukan para guru untuk memperbaiki kinerjanya dan mengembangkan keterampilan dan kompetensinya, dan bagaimana penyelenggara pelatihan dapat memberikan dukungan dan bimbingan.

Konsekuensi guru sebagai jabatan profesi dituntut untuk mengembangkan diri secara mandiri dan berkelanjutan agar dapat memiliki daya saing untuk memenangkan seleksi alam sumber daya yang berkualitas. Pelaksanaan PKB akan lebih efektif jika dilakukan secara sinergis oleh pemangku kepentingan, meliputi Dinas Pendidikan, LPTK sebagai penghasil calon guru, dan sekolah sebagai wahana kinerja guru. PKB harus dilaksanakan sesuai dengan kebutuhan guru untuk meningkatkan kompetensi dan profesionalitasnya, yang akan berimplikasi pada perolehan angka kredit untuk kenaikan pangkat/jabatan fungsional guru.

Menyadari hal tersebut, maka Dosen Program Studi Pendidikan Pancasila dan Kewarganegeraan IKIP PGRI Pontianak merasa perlu menyelenggarakan pelatihan penulisan artikel ilmiah untuk dipublikasikan ke dalam jurnal ilmiah berskala nasional yang berbasis Open Jurnal System (OJS) di Sekolah Menengah Pertama Kecamatan Kakap Kabupaten Kubu Raya.

\section{METODE}

Kegiatan pengabdian berupa pelatihan pembuatan media pembelajaran berbasis animasi. Khalayak sasaran kegiatan pengabdian adalah guru-guru Sekolah Dasar Kecamatan Sungai Raya yang berjumlah 30 guru. Pelaksanaan kegiatan pengabdian di SD Islam Daarul Hikmah. Alasan pemilihan lokasi tersebut dikarenakan potensi pengembangan keterampilan guru dalam menulis artikel sangat penting guna meningkatkan profesionalisme dan menambah nilai syarat kepangkatan guru.

Metode yang digunakan dalam kegiatan pengabdian adalah metode ceramah, diskusi, penugasan, dan tanya jawab dengan pendekatan andragogi yang ditunjang dengan media penunjang. Penyelenggaraan kegiatan terdiri atas presentasi penyampaian materi dan diskusi yang dilanjutkan dengan penyusunan artikel. Seminar diisi dengan dengan pemaparan materi pokok yang disampaikan oleh para narasumber yang menjelaskan substansi maeri-materi yang disampaikan 
berkenaan dengan program yang dibuat. Kemudian workshop dan pendampingan dalam pembuatan artikel ilmiah dan diskusi setelah penyampaian materi dan pada saat bedah (klinik) penulisan artikel. Selanjutnya, disampaikan pula kiat dan cara penulisan hasil penelitian ke dalam jurnal nasional yang disesuaikan dengan template jurnal.

\section{HASIL DAN PEMBAHASAN}

Kegiatan pengabdian pada masyarakat dilaksanakan pada 16-17 Maret 2018 bertempat di Sekolah Dasar Islam Daarul Hikmah yang berlokasi di Kecamatan Sungai Raya, Kabupaten Kubu Raya. Materi pelatihan disampaikan oleh narasumber dari Program Studi Pendidikan Pancasila dan Kewarganegaraan, Fakultas Ilmu Pendidikan dan Pengetahuan Sosial IKIP PGRI pontianak. Pelaksanaan pelatihan dilakukan dengan urutan materi sebagai berikut: (1) Penyampaian materi artikel ilmiah disampaikan oleh Bapak M. Anwar Rubei, M.Pd.; (2) Penyampaian materi publikasi ilmiah ke dalam jurnal berbasis OJS disampaikan oleh Bapak Moad, M.Pd.; (3) Tutorial penulisan artikel ilmiah dipandu oleh tim dosen Prodi PPKn; (4) Praktik penulisan artikel ilmiah dipandu oleh tim dosen Prodi PPKn; (5) Pembahasan tugas peserta dan penilaian hasil latihan dipandu oleh tim dosen Prodi PPKn; dan (6) Diskusi dan tanya jawab.

Pelaksanaan pelatihan diawali dengan kedatangan tim pengabdian ke SD Islam Daarul Hikmah pada tanggal 16 Maret 2018. Tim pengabdian dari Prodi PPKn IKIP PGRI Pontianak diterima secara langsung oleh Kepala SD Islam Daarul Hikmah. Selanjutnya dilakukan kegiatan pembukaan acara pelatihan secara bersama antara tim pengabdian Prodi PPKn IKIP PGRI Pontianak dengan Kepala SD Islam Daarul Hikmah. Setelah pembukaan, dilanjutkan dengan sesi pertama yaitu penyampaian materi tentang Pentingnya Menulis Artikel Ilmiah bagi Guru yang disampaikan oleh Bapak M. Anwar Rubei, M.Pd. Adapun simpulan materi yang disampaikan adalah bahwa kegiatan pengabdian pada guru dalam bidang kepenulisan sangat mendukung pengembangan kemampuan guru dalam menuju profesionalitasnya. 
Banyak manfaat yang dapat dirasakan ketika guru telah aktif menulis. Tujuan pengembangan kemampuan menulis karya ilmiah bagi guru adalah: (1) Guru akan lebih terampil dalam menulis artikel ilmiah; (2) Guru dapat menyebarluaskan gagasan dan temuannya melalui karya ilmiah yang dipublikasi ke dalam jurnal; (3) Guru lebih percaya diri dalam komunitasnya dan di hadapan siswanya; (4) Guru produktif dalam mengembangkan gagasannya secara tertulis; (5) Guru terhindar dari perilaku plagiat; dan (6) guru lebih cepat dalam mengembangkan karirnya.

Artikel ilmiah merupakan sejenis tulisan yang menyajikan atau menganalisis suatu topik secara ilmiah. Keilmiahan suatu tulisan didasarkan pada ragam bahasa yang digunakannya dan topik yang dikaji terkait dengan kepentingan ilmu. Ragam bahasa artikel ilmiah adalah ragam baku (standar). Karena situasi penulisan menuntut keresmian. Banyak orang yang ragu dalam pembuatan artikel ilmiah. Keraguan tersebut muncul terkait dengan berbagai pertanyaan, diantaranya: (1) Apakah topik yang akan disajikan tergolong ilmiah?; (2) Bagaimana menggunakan bahasa ilmiah untuk tulisan?; dan (3) Mampukah menuangkan berbagai gagasan ilmiah?. Kegiatan menulis merupakan kegiatan berbahasa secara produktif. Keproduktifannya tampak pada tulisan yang berisi gagasan yang tak terhingga. Dengan demikian, produk kegiatan menulis bukan hanya tulisan, melainkan juga gagasan. Gagasan yang dihasilkan dalam kegiatan menulis merupakan produk berpikir kreatif yang melibatkan aktivitas hemisfer kiri dan hemisfer kanan.

Ada dua bentuk artikel ilmiah, yaitu artikel konseptual yaitu artikel yang diangkat dari gagasan atau ide penulis dan artikel penelitian yang diangkat dari hasil penelitan. Perbedaan kedua jenis artikel tersebut terletak pada bagian isi. Jika dalam artikel konseptual antara bagian pendahuluan dan bagian penutup hanya berisi isi artikel yang bisa terdiri atas beberapa subbab; dalam artikel penelitian antara bagian pendahuluan dan bagian penutup terdapat bagian landasan teoretis, metodologi penelitian, serta hasil dan pembahasan.

Materi kedua disampaikan oleh Bapak Moad, M.Pd. dengan tema Publikasi Ilmiah ke dalam Jurnal. Jurnal ilmiah adalah sebuah jurnal akademik yang 
penulisnya (umumnya peneliti) mempublikasikan artikel ilmiah yang memberikan kontribusi terhadap teori atau penerarapan ilmu. Untuk memastikan kualitas ilmiah pada artikel yang diterbitkan, suatu artikel biasa diteliti oleh rekan-rekan sejawatnya dan direvisi oleh penulis, hal tersebut dikenal sebagai peer review (review oleh orang-orang yang lebih berkompeten). Terdapat berbagai jurnal ilmiah yang mencakup semua bidang ilmu, baik ilmu alam maupun ilmu sosial.

Setelah penyampaian materi pertama dan kedua, kegiatan dilanjutkan dengan istirahat, sholat, dan makan. Kemudian kegiatan dilanjutkan dengan penyampaian materi tentang Macam-Macam Jurnal Ilmiah dan Sistematika Artikel Jurnal. Pada hari kedua, Materi disampaikan oleh Bapak M. Anwar Rubei, M.Pd. dan Sy. Firmansyah. Peserta disampaikan tentang berbagai macam jurnal yang ada di IKIP-PGRI Pontianak. Jurnal-jurnal tersebut dapat diakses secara online melalui http://journal.ikippgriptk.ac.id. Melalui situs tersebut, peserta dapat mengetahui berbagai macam jurnal yang ada di IKIP-PGRI Pontianak, mengetahui tim redaktur, serta pedoman penulisan untuk setiap jurnal. Setiap jurnal juga memiliki pedoman penulisan yang berbeda. Oleh karenanya, artikel yang ditulis harus disesuaikan penulisannya sesuai dengan pedoman penulisan jurnal yang akan dituju. Beberapa contoh pedoman penulisan jurnal juga disampaikan, sehingga peserta memiliki pengetahuan yang lebih banyak dan diharapkan karya ilmiahnya dapat dipulikasikan pada jurnal yang diinginkan.

Setelah semua materi tersampaikan, kegiatan dilanjutkan dengan tutorial penulisan artikel ilmiah. Pada sesi tutorial penulisan artikel ilmiah, peserta diminta untuk mempresentasikan karya ilmiah yang pernah dibuat sebelumnya atau skripsi pada saat kuliah. Untuk peningkatan kenaikan pangkat dalam sesuai dengan aturan yang berlaku. Pada umumnya peserta mempresentasikan karya ilmiah yang dibuat sebelumnya berupa hasil penelitian tindakan kelas. Semua peserta dibimbing dalam membuat artikel berdasarkan pedoman/template jurnal IKIP-PGRI Pontianak. Proses pendampingan dilakukan oleh tim dosen Prodi PPKn sampai dengan menghasilkan artikel ilmiah. Artikel yang telah selesai di kerjakan kemudian dipresentasikan oleh peserta. Tugas dosen adalah mengoreksi 
artikel tersebut apakah sudah sesuai dengan template jurnal IKIP-PGRI Pontianak atau belum.

Di akhir kegiatan, seluruh peserta mengumpulkan artikel ilmiah yang telah dibuat sebelumnya. Artikel akan dibawa oleh tim dosen Prodi PPKn untuk diperiksa seluruhnya dan kemudian dikembalikan kepada peserta hasil koreksian tersebut, sehingga artikel tersebut siap untuk dipublikasikan ke dalam jurnal ilmiah yang berbasis OJS. Peserta diberikan jalur untuk mempubliskan artikelnya di IKIP-PGRI Pontianak maupun jurnal-jurnal lainnya yang sudah diberikan link/web. Jurnal di berbagai kampus yang ada di Kalimantan Barat maupun beberapa kampus yang ada di Indonesia.

Sebelum mengakhiri kegiatan, tim dosen memberikan kesempatan kepada peserta di akhir pelatihan. Sebagai evaluasi program dapat disimpulkan bahwa peserta menilai dan merespon kegiatan pelatihan secara positif. Seluruh peserta mengatakan bahwa pelatihan bermanfaat untuk memberikan dan/atau menambah wawasan dan keterampilan guru dalam menulis artikel ilmiah yang merupakan salah satu tuntutan profesionalisme sebagai guru dan peningkatan kenaikan pangkat/golongan.

Dari segi cakupan materi, secara umum peserta menyatakan bahwa materi yang disajikan memadai dan sesuai dengan harapan, yaitu dapat memahami urgensi penulisan karya tulis ilmiah untuk peningkatan karir dan pengetahuan tenaga pendidik, jenis-jenis artikel ilmiah, strategi penulisan karya ilmiah jurnal, macam-macam jurnal ilmiah, sistematika artikel jurnal. Diharapkan juga adanya pendampingan lebih lanjut dari tim pengabdian dalam melakukan pendampingan secara berkelanjutan dalam membuat artikel ilmiah di sekolah masing-masing.

Hasil akhir dari presentasi materi dan workshop menunjukkan adanya perubahan yang cukup berarti dalam hal wawasan guru tentang artikel ilmiah sehingga peserta dapat dengan penuh keyakinan dan kepercayaan mampu menulis artikel ilmiah sesuai dengan kaidah-kaidah yang benar. Setelah mengikuti pelatihan, seperti yang telah disebutkan dalam evaluasi program, peserta menyatakan bahwa akhirnya peserta memiliki gambaran yang jelas mengenai bagaimana membuat artikel ilmiah dan cara mempublikasikannya. 
Secara keseluruhan disimpulkan bahwa program kegiatan pengabdian diselenggarakan dengan baik yang ditandai dengan telah dihasilkannya artikel ilmiah dari peserta sesuai dengan kriteria yang benar. Selama pelatihan berlangsung, sangat terlihat antusiasme peserta untuk mengetahui banyak hal tentang artikel ilmiah dan publikasi ilmiah ke dalam jurnal. Hal tersebut terlaihat dari banyaknya pertanyaan yang diajukan oleh para peserta.

Berdasarkan hasil yang dicapai selama proses pelatihan dan setelah pelatihan yang meliputi keaktifan, antusiasme, dan kreativitas dalam menghasilkan artikel ilmiah, dapat dinyatakan bahwa kegiatan pelatihan yang telah dilakukan berhasil. Adapun hasil yang diperoleh adalah: (1) Meningkatnya kemauan peserta untuk menulis karya tulis ilmiah dan artikel ilmiah; (2) Meningkatnya wawasan dan pengetahuan guru terhadap artikel ilmiah; (3) Meningkatnya pengetahuan peserta dalam membedakan artikel ilmiah berbasis hasil penelitian dan non-penelitian; (4) Meningkatnya pengetahuan peserta terhadap jurnal berbasis OJS; (5) Meningkatnya keterampilan peserta dalam menulis artikel ilmiah; dan (6) Peserta mengetahui macam-macam jurnal ilmiah di IKIP-PGRI Pontianak yang dapat dipergunakan untuk mempublikasikan karya ilmiah.

\section{SIMPULAN}

Berdasarkan kegiatan pengabdian pada masyarakat yang telah dilaksanakan dalam bentuk pelatihan penulisan artikel ilmiah bagi guru di SD Islam Daarul Hikmah, maka dapat disimpulkan bahwa: (1) Terdapat peningkatan kepecayaan dan pemahaman tentang karya tulis ilmiah bagi pendidik mendesain laporan penelitian menjadi artikel imiah yang layak publikasi di jurnal ilmiah berbasis OJS; (2) Kegiatan pengabdian masayarakat berupa pelatihan menulis artikel ilmiah telah berhasil dilaksanakan dengan baik dan lancer yang ditunjukkan dengan guru peserta pelatihan dapat menjelaskan pengetahuan tentang pengertian penulisan artikel ilmiah, memahami jenis-jenis artikel ilmiah, dan mengetahui macam-macam jurnal ilmiah yang menjadi media untuk mempublikasikan jurnal; (3) Meningkatknya pengetahuan dan keterampilan guru peserta dalam menulis 
artikel ilmiah yang sesuai dengan pedoman atau template penulisan artikel ilmiah; dan (4) Guru peserta pelatihan telah menghasilkan artikel ilmiah yang siap untuk dipublikasikan di jurnal ilmiah.

Berdasarkan evaluasi dari pelaksanaan pengabdian di SD Islam Daarul Islam Kecamatan Sungai Raya Kabupaten Kubu Raya, maka disarankan: (1) Pengembangan keterampilan guru dalam menulis artikel ilmiah hendaknya terus ditingkatkan agar kualitas guru semakin baik sehingga dapat memberikan dampak pada pembelajaran yang semakin berkualitas; (2) Guru diharapkan untuk selalu proakatif mengikuti pelatihan penulisan artikel ilmiah dan menulis artikel ilmiah, serta mengirimkan artikel penelitiannya ke dalam jurnal nasional, bahkan jurnal internasional maupun prosiding. Hal tersebut merupakan langkah awal yang dapat dilakukan oleh guru untuk mengasah kemampuan menulisnya; (3) Sekolah hendaknya menjalin kerja sama dengan perguruan tinggi. Bentuk kerja sama adalah berupa pembimbingan dari perguruan tinggi kepada para guru dalam melakukan pelatihan dan pendampingan penulisan artikel ilmiah yang dipublikasikan. Kepala sekolah disarankan membentuk forum ilmiah guru yang merupakan wahana para guru dalam berdiskusi, seminar ilmiah ataupun diseminasi karya ilmiahnya; dan (4) Bagi pelaksana pengabdian selanjutnya agar menyelenggarakan kegiatan workshop penulisan artikel ilmiah, baik di wilayah kota ataupun di wilayah kabupaten lain, dengan menggunakan pendekatan pendampingan klinis.

\section{UCAPAN TERIMA KASIH}

Terima kasih diucapkan kepada pihak mitra pengabdian kepada masyarakat yakni guru-guru SD Kecamatan Sungai Raya Kabupaten Kubu Raya atas partisipasi dan kerja samanya. Serta IKIP-PGRI Pontianak yang telah memberikan bantuan dana untuk kelancaran kegiatan pengabdian kepada masyarakat.

\section{DAFTAR PUSTAKA}

Amrullah. 2004. Pengantar Manajemen, Yogyakarta: Graha Ilmu. 
Badan Kepegawaian Negara Nomor 14 tahun 2010 tentang Petunjuk Pelaksanaan Jabatan Fungsional Guru dan Angka Kredit.

Direktorat Jenderal Pendidikan Tinggi Kemendikbud RI. 2013. Panduan Pelaksanaan Penelitian dan Pengabdian Kepada Masyarakat di Perguruan Tinggi Edisi IX Tahun 2013.

Lembaga Pengabdian kepada Masyarakat. 2017. Buku Panduan Pelaksanaan Pengabdian kepada Masyaraka Edisi 2. Pontianak: IKIP PGRI Pontianak.

Permeneg PAN dan RB Nomor 16 Tahun 2009 tentang Jabatan Fungsional Guru dan Angka Kreditnya.

Permendiknas Nomor 35 Tahun 2010 tentang Petunjuk Teknis Pelaksanaan Jabatan Fungsional Guru dan Angka Kreditnya

Undang-Undang Nomor 20 Tahun 2003, tentang Sistem Pendidikan Nasional.

Undang-Undang Nomor 14 Tahun 2005 tentang Guru dan Dosen. 